\title{
Sedanterlerde Kinezyofobinin Çeşitli Değişkenlere Göre İncelenmesi
}

\author{
Furkan ERGÜL ${ }^{1}$ Hulusi ALP*1(D)
}

${ }^{1}$ Süleyman Demirel Üniversitesi, Spor Bilimleri Fakültesi.

Orijinal Makale

Gönderi Tarihi: 11.06.2021
Kabul Tarihi: 23.06.2021
DOI: $10.30769 /$ usbd.913082

Online Yayın Tarihi: 30.06.2021

\section{Öz}

Araştırmanın amacı, sedanter bireylerin kinezyofobi düzeylerini çeşitli değişkenler açısından incelemektir. Araştırma tarama modelinde yapılmıştır. Araştırmaya, 17-60 yaş aralığında çeşitli bölgelerinde uzun süreli ağrıları bulunan 114 gönüllü katılmıştır. Veri toplamak amacıyla, Tampa Kinezyofobi Ölçeği kullanılmıştır. Veriler normal dağılım göstermediği için, iki değişken arasındaki analizlerde Mann Whitney U Test, ikiden fazla değişken arasındaki analizlerde ise Kruskal Wallis H Test ve Post-Hoc (Tamhane's T2) test kullanılmıştır. Tampa Kinezyofobi Ölçeğinde toplam puanlara bakıldığında kadınlar ve erkekler arasında anlamlı bir fark bulunamamıştır. Öğrenim açısından ortaokul, lise ve üniversite arasında toplam skorda anlamlı bir fark bulunmuştur. Mesleki açıdan avukat, öğrenci, mühendis, öğretmen ve diğer olarak ayrılan gruplar arasında incelediğimizde de gruplar arasında anlamlı bir fark bulunmuştur. Kronik ağrılı hastalarda kinezyofobide erkekler ile kadınlar arasında fark yokken öğrenim durumu ve mesleğin kinezyofobiyi etkilediği görülmüştür.

Anahtar kelimeler: Kinezyofobi, ağrl, sedanter.

\section{Invertigation of Kinesiophobia According to Various Variables}

\begin{abstract}
The aim of the study is to examine the kinesophobia levels of sedentary individuals in terms of various variables. The research has been done in scanning model. A total of 114 volunteers, aged 17-60, with prolonged pain in various regions, participated in the study. Tampa Kinesophobia Scale was used to collect data. Since the data did not show a normal distribution, Mann Whitney U Test was used for analysis between two variables, and Kruskal Wallis H Test and Post-Hoc (Tamhane's T2) test was used for analysis between more than two variables. When the total scores on the Tampa Kinesophobia Scale were examined, no significant difference was found between men and women. A significant difference was found in the total score between secondary school, high school and university in terms of education. When we examined the groups divided into lawyers, students, engineers, teachers and others in terms of occupation, a significant difference was found between the groups. While there was no difference in kinesiophobia between men and women in patients with chronic pain, it was observed that educational status and occupation affected kinesiophobia.

Keywords: Kinesiophobia, pain, sedentary.
\end{abstract}

*Sorumlu Yazar: Hulusi ALP, Doç. Dr., E-posta: ekim1778@gmail.com 


\section{GíRIŞ}

İnsanlar, teknoloji çok fazla gelişmeden önce yapılacak işlerini teknolojiden yardım alamadan kendi uğraşları ve kendi bedenlerini kullanarak yapıyordu. Ancak günümüzde bilim ve teknolojinin gelişimi ile imkanlar çok artmıştır. İnsanlar bu gelişmeler ile teknolojiden yararlanarak işlerini kolayca hatta hareket bile etmeden yapabilecek duruma gelmişlerdir. Bu da insan hayatında hem olumlu hem de olumsuz birçok duruma yol açmıştır (Duran, 2020).

Teknolojideki bu gelişmeler hayatımızı çok kolaylaştırsa da bizleri hareketsizliğe veya çok az hareket etmeye yönlendirdiği için vücudumuzda hantallı̆̆a, çeşitli problemlere, yaralanmalara veya diğer olumsuzluklara yol açabilmektedir (Özmen vd., 2016). Bir başka deyişle teknolojik gelişmeler günümüz insanın sedanter bir duruma gelmesine de sebep olmaktadır. Sedanter yaşam, vücudun harcayacağı enerjiyi minimum şekilde harcaması durumudur. Yani bu da sedanterlerde kişinin dinlenik haldeki ve normal yaşamındaki kalp atım hızının yaklaşık olarak eşit olması anlamına gelmektedir (Sarıdede, 2019). Kişiler yaşamlarının herhangi bir döneminde bir yaralanma geçirdiğinde buna bağlı hareket kısıtlanması yaşayabilirler ve tekrar yaralanırım korkusu ile hareketten kaçınabilirler, hatta bu da yaşanılan korku nedeniyle iyileşme sürecinin sonunda dahi kişinin hareketten kaçınmasına neden olabilir. Bunun sonucu olarak da kişilerde Kinezyofobi dediğimiz durum ortaya ç1kabilmektedir (Y1lmaz vd., 2011).

Kinezyofobi; aşırı, mantıksız, zayıflatıcı hareket korkusu ve fiziksel aktiviteden kaynaklanan ağrılı yaralanma veya tekrar yaralanmaya karşı savunmasız olma hissi olarak tanımlanmıştır (Kori vd., 1990; Vlaeyen vd., 1995). Ayrıca kinezyofobi yaşanan bir olay veya yaralanmaya bağlı olarak ağrılı bir durumda hareket etmeye karşı oluşmuş bir kaçınma durumudur diye de tanımlanabilir (Dere, 2020). Ağrı nedeniyle ortaya çıkan bu korkunun, kişiyi ağrının kendisinden çok daha fazla kısıtladığı saptanmıştır (Lundberg vd., 2006). Ağrı, dokunun zedelenmesiyle, vücudun çeşitli yerlerinde ortaya çıkan, rahatsız edici bir duyusal bir histir (Tekin, 2010). Bir ağrı sonrasında ortaya çıkan kinezyofobi günlük yaşamda kısıtlanmalara neden olur bunun sonucunda da vücutta kuvvet kaybı, esneklik kaybı, postür bozukluğu gibi problemler ortaya çıkabilir (Uçurum ve Kalkan, 2018). Kişinin ağrıdan kaçmak için hareket etme biçimini değiştirmesi ağrının kontrol ve denetimini kötü yönde etkilemektedir (Güzel vd., 2021). Kinezyofobisi olan insanlarda yapilan hareketin tekrardan bir yaralanmaya sebep olacağı inancı vardır, bu da ağrının vücutta uzun süre kalıp kronikleşmesine neden olabilmektedir (Uçurum ve Kalkan, 2018).

Yapılan çalışmalarda insan hayatında kinezyofibiden dolayı ortaya çıkan korkunun ağrıdan daha fazla kısıtlayıcı rolü olduğunu göstermiştir (Devaşan, 2014; Lungberg vd., 2006). Ortaya çıkan kinezyofobi günlük yaşamda da kısıtlanmalara neden olmaktadır bunun sonucunda da vücutta kuvvet kaybı, esneklik kaybı, postür bozukluğu gibi problemler ortaya çıkabilmektedir (Uçurum ve Kalkan, 2018). Yapılan çalışmalarda; meydana gelen kronik bel ağrısı, üst ekstremite problemleri, ortopedik yaralanmalar ve aşırı kullanım yaralanması tanılı hasta gruplarında ileri düzeyde kinezyofobi bulunduğu bilinmektedir (Kaygusuz, 2018; Özkal vd., 2017). Böylelikle kişide kinezyofobik davranış oluşması ile hareket, egzersiz, spor gibi aktivitelerin azaldığı görülmekte bu da kişinin fiziksel durumunun yanında mental durumunu da etkilemektedir (Devaşan, 2014). Kinezyofobinin bu gibi ortaya çıkardığı problemlere ek olarak kişide kaygı bozuklukları ve depresyon gibi durumlar da görülebilir (Bilge, 2017). Bu da oluşan problemlerle birlikte kişinin insanlardan soyut bir hayat yaşamasına ve psikolojik sıkıntılarının oluşmasına neden olabilmektedir (Özmen vd., 2016). Ayrıca kinezyofobinin ortaya çıkması ile de kişinin yaşam kalite standartlarının düştüğü görülmüştür (Haspolar, 
2017). Kişilerde bahsedildiği gibi kinezyofobi nedenli meydana gelen aktivitelere katılımın azalmasına ve hareketsiz bir yaşamın oluşmasına korku-kaçınma davranışı denir (Güney, 2019). Bu davranışın erken tespiti ilerde bunu ve bununla birlikte oluşabilecek sedanter yaşamın oluşturabileceği problemlerin engellenebilmesi için çok önemlidir. Bu kişilere göre düzenlenecek fiziksel aktivite, düzenli egzersiz programları ve sosyal yaşam ile kişinin sedanter yaşam biçimi en aza indirilmeye çalışılmalı ve kişinin hayatının ilerleyen döneminde karşılaşabileceği risk faktörlerinin azaltılması amaçlanmalıdır (Özmen vd., 2016). Araştırmanın amacı, sedanter bireylerin kinezyofobi düzeylerini çeşitli değişkenler (cinsiyet, meslek, öğrenim durumu gibi) açısından incelemektir.

\section{YÖNTEM}

\section{Araştırmanın modeli}

Araştırma tarama modelinde yapılmıştır. Tarama modeli geçmiş zamanda olmuş veya şu anda var olan bir olayı olduğu haliyle anlatmaya çalışan ve çalışmadaki kişi, obje ve durumu olduğu gibi anlatan modeldir (Uzun ve Ayık, 2016). Deneysel olmayan araştırma modelinde araştırmacı herhangi bir müdahalede bulunmaz. Var olan durum olduğu gibi araştırma kapsamında incelenmektedir (Şata, 2020).

\section{Araştırma Evren ve Örneklemi}

Kırşehir il merkezinde yaşayan, uzun süredir vücudunun çeşitli yerlerinde ağrıları bulunan ve araştırmaya gönüllü olarak katılmayı kabul eden 114 kişi (62 kadın - 52 erkek) katılım sağlamıştır. Olasılığa dayalı olmayan örneklem seçim tekniklerinden, uygun örnekleme yöntemi kullanılmıştır. Uygun örnekleme yöntemi; zaman, para ve işgücü açısından var olan sınırlılıklar nedeniyle, yapılacak çalışma için mevcut durumların kullanılmasını içermektedir (Çobanoğlu, 2020; İlhan, vd., 2016).

\section{Veri Toplama Aracı}

Araştırmada, ilk olarak 1991 yılında Miller ve diğerleri tarafından oluşturulan ama yayınlanmayan, Vlayen ve diğerleri tarafından gerekli onaylar alınarak 1995'te geliştirilen Tampa Kinezyofobi Ölçeğinin, Yılmaz ve diğerleri (2011) tarafindan Türkçe' ye uyarlanmış son hali kullanılmıştır. Ölçek, 17 sorudan oluşan ve her soru için 4 farklı puanın alınabileceği bir değerlendirme formudur. Ölçekte sorulan sorulardan alınan puanlara göre bir birey en çok 68 en az 17 skor alabilir. Burada genel puanlamada alınan skor ne kadar yüksekse bireyin kinezyofobisi de o kadar çoktur anlamına gelmektedir. Testin, güvenirlik katsayısı 0.80 olarak hesaplanmıştır.

\section{Verilerin Toplanması}

Bu araştırma 2020 Aralık ve 2021 Ocak aylarında çalışmada kullanılan ölçek, Google Forms üzerinden hazırlandıktan sonra araştırmanın evrenini oluşturan bireylere anketin linki sosyal iletişim ağları ve sosyal medya hesapları üzerinden iletilmiştir. Araştırmaya gönüllü olarak katılmayı kabul ederen ve anketi dolduran kişilerin verileri system tarafından otomatik olarak kayıt altına alınmıştır. Kayıt altına alının toplam verilerin excel çıktısı alınarak daha sonra istatistik analiz programına girişleri yapılmıştır.

\section{Verilerin analizi}

Verilerin normal dağılım gösterip göstermediğine bakılmış ve veriler normal dağılım göstermediği için, iki değişken arasındaki analizlerde Mann Whitney U Testi, ikiden fazla değişkenler arasındaki analizlerde ise Kruskal Wallis H Test ve Post-Hoc (Tamhane's T2) test ile yapılmıştır. 


\section{BULGULAR}

Tablo 1. Sedanter bireylerin demografik verilerinin frekans ve yüzde dağılımları

\begin{tabular}{llcc}
\hline Değişkenler & & f & \% \\
\hline \multirow{4}{*}{ Yaş } & $18-25$ yaş arası & 53 & 46,5 \\
& $26-35$ yaş arası & 8 & 7,0 \\
& $36-45$ yaş arası & 19 & 16,7 \\
& $46-59$ yaş arası & 34 & 29,8 \\
Cinsiyet & Toplam & 114 & 100 \\
& Kadın & 62 & 54,4 \\
& Erkek & 52 & 45,6 \\
& Toplam & 114 & 100 \\
\hline \multirow{3}{*}{ Eğitim Durumu } & Ortaokul & 13 & 11,4 \\
& Lise & 19 & 16,7 \\
& Üniversite & 82 & 71,9 \\
& Toplam & 114 & 100 \\
\hline
\end{tabular}

Tablo 1'de sedanter bireylerin demografik özelliklerine ilişkin tanımlayıcı istatistikler görülmektedir. Kendi kategorisindeki en yüksek değişkenler sırasıyla yaş değişkeninde \%46,5 ile 17-25 yaş aralığındaki sedanterler, \%54,4 ile kadın sedanter bireyler, \%71,9 ile de eğitim durumu üniversite olan sedanter bireyler olmuştur.

Tablo 2. Sedanter bireylerin cinsiyet değişkenine göre kinezyofobilerinin karşılaştırılması

\begin{tabular}{|c|c|c|c|c|c|c|c|}
\hline & Cinsiyet & $\mathbf{N}$ & Mean Rank & Sum of Ranks & $\mathbf{Z}$ & $\mathbf{U}$ & $p$ \\
\hline \multirow{2}{*}{$\begin{array}{l}\text { Egzersiz yaparsam kendi } \\
\text { kendime sakatlanırım diye } \\
\text { korkuyorum }\end{array}$} & Erkek & 52 & 47,97 & 2494,50 & \multirow[b]{2}{*}{$-3,078$} & \multirow[b]{2}{*}{1116,500} & \multirow[b]{2}{*}{, $002 *$} \\
\hline & Kadın & 62 & 65,49 & 4060,50 & & & \\
\hline \multirow{2}{*}{$\begin{array}{l}\text { Ağrımla baş etmeye çalışacak } \\
\text { olsam ağrım artar }\end{array}$} & Erkek & 52 & 50,62 & 2632,00 & \multirow{2}{*}{$-2,314$} & \multirow{2}{*}{1254,000} & \multirow{2}{*}{,021* } \\
\hline & Kadın & 62 & 63,27 & 3923,00 & & & \\
\hline \multirow{2}{*}{$\begin{array}{l}\text { Ağrımdan dolayı vücudum bana } \\
\text { tehlikeli derecede yanlış giden } \\
\text { bir şeyler olduğunu söylüyor }\end{array}$} & Erkek & 52 & 55,92 & 2908,00 & \multirow[b]{2}{*}{,- 503} & \multirow[b]{2}{*}{1530,000} & \multirow[b]{2}{*}{,615 } \\
\hline & Kadın & 62 & 58,82 & 3647,00 & & & \\
\hline \multirow{2}{*}{$\begin{array}{l}\text { Egzersiz yaparsam sanki ağrım } \\
\text { hafifleyecekmiş gibi geliyor }\end{array}$} & Erkek & 52 & 58,48 & 3041,00 & \multirow{2}{*}{,- 329} & \multirow{2}{*}{1561,000} & \multirow{2}{*}{, 742} \\
\hline & Kadın & 62 & 56,68 & 3514,00 & & & \\
\hline \multirow{2}{*}{$\begin{array}{l}\text { İnsanlar benim tıbbi sorunlarımı } \\
\text { yeterince ciddiye almıyorlar }\end{array}$} & Erkek & 52 & 59,92 & 3116,00 & \multirow{2}{*}{,- 780} & \multirow{2}{*}{1486,000} & \multirow{2}{*}{,435 } \\
\hline & Kadın & 62 & 55,47 & 3439,00 & & & \\
\hline \multirow{2}{*}{$\begin{array}{l}\text { Başıma gelen bu olay nedeni ile } \\
\text { vücudum hayat boyu risk } \\
\text { altında olacak }\end{array}$} & Erkek & 52 & 59,98 & 3119,00 & \multirow[b]{2}{*}{,- 873} & \multirow[b]{2}{*}{1483,000} & \multirow[b]{2}{*}{, 383} \\
\hline & Kadın & 62 & 55,42 & 3436,00 & & & \\
\hline
\end{tabular}


Tablo 2 (Devamı). Sedanter bireylerin cinsiyet değişkenine göre kinezyofobilerinin karşılaştırılması

\begin{tabular}{|c|c|c|c|c|c|c|c|}
\hline & Cinsiyet & $\mathbf{N}$ & Sura Ort. & Sıralar Toplamı & $\mathbf{Z}$ & $\mathbf{U}$ & $p$ \\
\hline \multirow{2}{*}{$\begin{array}{l}\text { Ağrımın olması her zaman } \\
\text { vücudumu sakatladığım/bir } \\
\text { problemim olduğu anlamına gelir }\end{array}$} & Erkek & 52 & 61,00 & 3172,00 & \multirow[b]{2}{*}{$-1,199$} & \multirow[b]{2}{*}{1430,000} & \multirow[b]{2}{*}{,230 } \\
\hline & Kadın & 62 & 54,56 & 3383,00 & & & \\
\hline \multirow{2}{*}{$\begin{array}{l}\text { Sırf bazı şeylerin ağrımı artırıyor } \\
\text { olması onların tehlikeli oldukları } \\
\text { anlamına gelmez }\end{array}$} & Erkek & 52 & 57,94 & 3013,00 & \multirow[b]{2}{*}{,- 161} & \multirow[b]{2}{*}{1589,000} & \multirow[b]{2}{*}{, 872} \\
\hline & Kadın & 62 & 57,13 & 3542,00 & & & \\
\hline \multirow{2}{*}{$\begin{array}{l}\text { Kendimi kazara sakatlamaktan } \\
\text { korkuyorum }\end{array}$} & Erkek & 52 & 51,08 & 2656,00 & \multirow{2}{*}{$-2,079$} & \multirow{2}{*}{1278,000} & \multirow{2}{*}{,038* } \\
\hline & Kadın & 62 & 62,89 & 3899,00 & & & \\
\hline \multirow{2}{*}{$\begin{array}{l}\text { Ağrının artmasını engellemenin en } \\
\text { basit ve güvenli yolu gereksiz } \\
\text { hareketler yapmaktan kaçınmaktır }\end{array}$} & Erkek & 52 & 55,90 & 2907,00 & \multirow[b]{2}{*}{,- 506} & \multirow[b]{2}{*}{1529,000} & \multirow[b]{2}{*}{,613 } \\
\hline & Kadın & 62 & 58,84 & 3648,00 & & & \\
\hline \multirow{2}{*}{$\begin{array}{l}\text { Vücudumda tehlike arz eden bir } \\
\text { şey olmasaydı bu kadar çok ağrı } \\
\text { hissetmezdim }\end{array}$} & Erkek & 52 & 58,19 & 3026,00 & \multirow[b]{2}{*}{,- 224} & \multirow[b]{2}{*}{1576,000} & \multirow[b]{2}{*}{,823 } \\
\hline & Kadın & 62 & 56,92 & 3529,00 & & & \\
\hline \multirow{2}{*}{$\begin{array}{l}\text { Ağrıma rağmen fiziksel olarak } \\
\text { aktif olsaydım durumum daha iyi } \\
\text { olurdu }\end{array}$} & Erkek & 52 & 57,08 & 2968,00 & \multirow[t]{2}{*}{,- 147} & \multirow[t]{2}{*}{1590,000} & \multirow[t]{2}{*}{, 883} \\
\hline & Kadın & 62 & 57,85 & 3587,00 & & & \\
\hline \multirow{2}{*}{$\begin{array}{l}\text { Ağrı kendimi sakatlamamam için } \\
\text { egzersizi ne zaman bırakmam } \\
\text { gerektiği konusunda bana sinyal } \\
\text { verir }\end{array}$} & Erkek & 52 & 66,37 & 3451,00 & \multirow[b]{2}{*}{$-2,991$} & \multirow[b]{2}{*}{1151,000} & \multirow[b]{2}{*}{, $003 *$} \\
\hline & Kadın & 62 & 50,06 & 3104,00 & & & \\
\hline \multirow{2}{*}{$\begin{array}{l}\text { Benim durumumda olan birinin } \\
\text { fiziksel olarak aktif olması pek } \\
\text { güvenli değildir }\end{array}$} & Erkek & 52 & 55,24 & 2872,50 & \multirow[b]{2}{*}{,- 783} & \multirow[b]{2}{*}{1494,500} & \multirow[b]{2}{*}{,434 } \\
\hline & Kadın & 62 & 59,40 & 3682,50 & & & \\
\hline \multirow{2}{*}{$\begin{array}{l}\text { Normal insanların yaptığı her şeyi } \\
\text { yapamam çünkü çok kolay } \\
\text { sakatlanırım }\end{array}$} & Erkek & 52 & 56,75 & 2951,00 & \multirow[b]{2}{*}{,- 252} & & \\
\hline & Kadın & 62 & 58,13 & 3604,00 & & 1573,000 & ,801 \\
\hline Bazı şeyler çok fazla ağrıya neden & Erkek & 52 & 54,53 & 2835,50 & & & \\
\hline $\begin{array}{l}\text { olsa bile bunların gerçekte tehlikeli } \\
\text { olduklarını düşünmem }\end{array}$ & Kadın & 62 & 59,99 & 3719,50 &,- 990 & 1457,500 & ,332 \\
\hline Hiç kimse ağnı hissederken egzersiz & Erkek & 52 & 53,45 & 2779,50 & -1.290 & 1401.500 & 197 \\
\hline yapmak zorunda olmamalı & Kadın & 62 & 60,90 & 3775,50 & $-1,290$ & 1401,500 & , 191 \\
\hline
\end{tabular}

Cinsiyet değişkeni açısından, sedanter bireylerin, Egzersiz yaparsam kendi kendime sakatlanırım diye korkuyorum, Ă̆rımla baş etmeye çalışacak olsam ă̆rım artar, Kendimi kazara sakatlamaktan korkuyorum, A ğr kendimi sakatlamamam için egzersizi ne zaman bırakmam gerektiği konusunda bana sinyal verir, ölçek maddeleri arasında istatistiksel olarak anlamlı fark olduğu görülmektedir (Tablo 2) $(\mathrm{p}<0.05)$. 
Tablo 3. Sedanter bireylerin eğitim düzeyi değişkenine göre kinezyofobilerinin karşılaştırılması

\begin{tabular}{|c|c|c|c|c|c|c|c|}
\hline & $\begin{array}{l}\text { Öğrenim } \\
\text { Durumu }\end{array}$ & $\mathbf{N}$ & Sira Ort. & $\mathbf{X}^{2}$ & sd & $p$ & Tamhane's T2 \\
\hline \multirow{3}{*}{$\begin{array}{l}\text { Egzersiz yaparsam kendi } \\
\text { kendime sakatlanırım diye } \\
\text { korkuyorum }\end{array}$} & (1) Ortaokul & 13 & 74,38 & \multirow{3}{*}{10,284} & \multirow{3}{*}{2} & \multirow{3}{*}{, $006 *$} & $1>3$ \\
\hline & (2) Lise & 19 & 70,29 & & & & \\
\hline & (3) Üniversite & 82 & 51,86 & & & & \\
\hline \multirow{3}{*}{$\begin{array}{l}\text { Ağrımla baş etmeye } \\
\text { çalışacak olsam ağrım artar }\end{array}$} & (1) Ortaokul & 13 & 67,96 & \multirow{3}{*}{2,043} & \multirow{3}{*}{2} & \multirow{3}{*}{,360 } & \\
\hline & (2) Lise & 19 & 58,45 & & & & \\
\hline & (3) Üniversite & 82 & 55,62 & & & & \\
\hline \multirow{3}{*}{$\begin{array}{l}\text { Ağrımdan dolayı vücudum } \\
\text { bana tehlikeli derecede yanlış } \\
\text { giden bir şeyler olduğunu } \\
\text { söylüyor }\end{array}$} & (1) Ortaokul & 13 & 54,73 & \multirow{3}{*}{,264 } & \multirow{3}{*}{2} & \multirow{3}{*}{, 876} & \\
\hline & ${ }^{(2)}$ Lise & 19 & 60,26 & & & & \\
\hline & (3) Üniversite & 82 & 57,30 & & & & \\
\hline \multirow{3}{*}{$\begin{array}{l}\text { Egzersiz yaparsam sanki } \\
\text { ağrım hafifleyecekmiş gibi } \\
\text { geliyor }\end{array}$} & (1) Ortaokul & 13 & 66,27 & \multirow{3}{*}{2,345} & \multirow{3}{*}{2} & \multirow{3}{*}{,310 } & \\
\hline & (2) Lise & 19 & 62,45 & & & & \\
\hline & (3) Üniversite & 82 & 54,96 & & & & \\
\hline \multirow{3}{*}{$\begin{array}{l}\text { İnsanlar benim tıbbi } \\
\text { sorunlarımı yeterince ciddiye } \\
\text { almıyorlar }\end{array}$} & (1) Ortaokul & 13 & 65,69 & \multirow{3}{*}{5,274} & \multirow{3}{*}{2} & \multirow{3}{*}{,072 } & \\
\hline & (2) Lise & 19 & 69,32 & & & & \\
\hline & (3) Üniversite & 82 & 53,46 & & & & \\
\hline \multirow{3}{*}{$\begin{array}{l}\text { Başıma gelen bu olay nedeni } \\
\text { ile vücudum hayat boyu risk } \\
\text { altında olacak }\end{array}$} & (1) Ortaokul & 13 & 69,62 & \multirow{3}{*}{9,520} & \multirow{3}{*}{2} & \multirow{3}{*}{, $009 *$} & \\
\hline & (2) Lise & 19 & 70,84 & & & & $2>3$ \\
\hline & (3) Üniversite & 82 & 52,49 & & & & \\
\hline \multirow{3}{*}{$\begin{array}{l}\text { A ğrımın olması her zaman } \\
\text { vücudumu sakatladığım/bir } \\
\text { problemim olduğu anlamına } \\
\text { gelir }\end{array}$} & (1) Ortaokul & 13 & 63,42 & \multirow{3}{*}{3,754} & \multirow{3}{*}{2} & \multirow{3}{*}{,153 } & \\
\hline & (2) Lise & 19 & 67,16 & & & & \\
\hline & (3) Üniversite & 82 & 54,32 & & & & \\
\hline \multirow{3}{*}{$\begin{array}{l}\text { Sırf bazı şeylerin ağrımı } \\
\text { artırıyor olması onların } \\
\text { tehlikeli oldukları anlamına } \\
\text { gelmez }\end{array}$} & (1) Ortaokul & 13 & 58,31 & & & & \\
\hline & (2) Lise & 19 & 60,74 & 375 & 2 &, 829 & \\
\hline & (3) Üniversite & 82 & 56,62 & & & & \\
\hline & (1) Ortaokul & 13 & 63,62 & & & & \\
\hline Kendimı kazara & (2) Lise & 19 & 57,08 & 605 & 2 & ,739 & \\
\hline & (3) Üniversite & 82 & 56,63 & & & & \\
\hline Ağrının artmasını & (1) Ortaokul & 13 & 59,65 & & & & \\
\hline engellemenin en basit ve & (2) Lise & 19 & 51,79 & & & & \\
\hline güvenli yolu gereksiz & & & & ,798 & 2 & 671 & \\
\hline $\begin{array}{l}\text { hareketler yapmaktan } \\
\text { kacınmaktır }\end{array}$ & (3) Üniversite & 82 & 58,48 & & & & \\
\hline
\end{tabular}


Tablo 3 (Devamı). Sedanter bireylerin eğitim düzeyi değişkenine göre kinezyofobilerinin karşılaştırılması

\begin{tabular}{|c|c|c|c|c|c|c|c|}
\hline & $\begin{array}{l}\text { Öğrenim } \\
\text { Durumu }\end{array}$ & $\mathbf{N}$ & Sira Ort. & $\mathbf{X}^{2}$ & sd & $p$ & Tamhane's T2 \\
\hline \multirow{3}{*}{$\begin{array}{l}\text { Vücudumda tehlike arz eden } \\
\text { bir şey olmasaydı bu kadar } \\
\text { çok ağrı hissetmezdim }\end{array}$} & (1) Ortaokul & 13 & 63,35 & \multirow{3}{*}{7,114} & \multirow{3}{*}{2} & \multirow{3}{*}{, $029 *$} & \\
\hline & ${ }^{(2)}$ Lise & 19 & 72,76 & & & & $2>3$ \\
\hline & (3) Üniversite & 82 & 53,04 & & & & \\
\hline \multirow{3}{*}{$\begin{array}{l}\text { Ağrıma rağmen fiziksel } \\
\text { olarak aktif olsaydım } \\
\text { durumum daha iyi olurdu }\end{array}$} & (1) Ortaokul & 13 & 59,62 & \multirow{3}{*}{,323 } & \multirow{3}{*}{2} & \multirow{3}{*}{, 851} & \\
\hline & (2) Lise & 19 & 54,37 & & & & \\
\hline & (3) Üniversite & 82 & 57,89 & & & & \\
\hline \multirow{3}{*}{$\begin{array}{l}\text { Ağrı kendimi sakatlamamam } \\
\text { için egzersizi ne zaman } \\
\text { bırakmam gerektiği } \\
\text { konusunda bana sinyal verir }\end{array}$} & (1) Ortaokul & 13 & 61,19 & \multirow{3}{*}{, 720} & \multirow{3}{*}{2} & \multirow{3}{*}{,698 } & \\
\hline & (2) Lise & 19 & 61,18 & & & & \\
\hline & (3) Üniversite & 82 & 56,06 & & & & \\
\hline \multirow{3}{*}{$\begin{array}{l}\text { Benim durumumda olan } \\
\text { birinin fiziksel olarak aktif } \\
\text { olması pek güvenli değildir }\end{array}$} & (1) Ortaokul & 13 & 71,85 & \multirow{3}{*}{5,376} & \multirow{3}{*}{2} & \multirow{3}{*}{,068 } & \\
\hline & (2) Lise & 19 & 63,00 & & & & \\
\hline & (3) Üniversite & 82 & 53,95 & & & & \\
\hline \multirow{3}{*}{$\begin{array}{l}\text { Normal insanların yaptığı her } \\
\text { şeyi yapamam çünkü çok } \\
\text { kolay sakatlanırım }\end{array}$} & (1) Ortaokul & 13 & 74,35 & \multirow{3}{*}{5,350} & \multirow{3}{*}{2} & \multirow{3}{*}{,069 } & \\
\hline & ${ }^{(2)}$ Lise & 19 & 59,29 & & & & \\
\hline & (3) Üniversite & 82 & 54,41 & & & & \\
\hline \multirow{3}{*}{$\begin{array}{l}\text { Bazı şeyler çok fazla ağrıya } \\
\text { neden olsa bile bunların } \\
\text { gerçekte tehlikeli olduklarını } \\
\text { düşünmem }\end{array}$} & (1) Ortaokul & 13 & 58,50 & \multirow{3}{*}{1,522} & \multirow{3}{*}{2} & \multirow{3}{*}{,467 } & \\
\hline & (2) Lise & 19 & 64,82 & & & & \\
\hline & (3) Üniversite & 82 & 55,65 & & & & \\
\hline \multirow{3}{*}{$\begin{array}{l}\text { Hiç kimse ağrı hissederken } \\
\text { egzersiz yapmak zorunda } \\
\text { olmamalı }\end{array}$} & (1) Ortaokul & 13 & 67,27 & \multirow{3}{*}{1,837} & \multirow{3}{*}{2} & \multirow{3}{*}{,399 } & \\
\hline & (2) Lise & 19 & 60,00 & & & & \\
\hline & (3) Üniversite & 82 & 55,37 & & & & \\
\hline
\end{tabular}

Eğitim durumu değişkeni açısından, sedanter bireylerin, Egzersiz yaparsam kendi kendime sakatlanırım diye korkuyorum, Başıma gelen bu olay nedeni ile vücudum hayat boyu risk altında olacak, Vücudumda tehlike arz eden bir şey olmasaydl bu kadar çok ağrı hissetmezdim, ölçek maddeleri arasında istatistiksel olarak anlamlı bir fark görülmüştür (Tablo 3) $(\mathrm{p}<0,05)$. Farkın hangi değişkenler arasında olduğunu tespit etmek için yapılan Post-Hoc (Tamhane's T2) test sonucuna göre, eğitim durumu üniversite olan bireyler ile eğitim durumu ortaokul olan bireyler arasında olduğu görülmektedir. 
Tablo 4. Sedanter bireylerin yaş değişkenine göre kinezyofobilerinin karşıllaştırılması

\begin{tabular}{|c|c|c|c|c|c|c|c|}
\hline & Yaş & $\mathbf{N}$ & Sira Ort. & $\mathbf{X}^{2}$ & sd & $p$ & Tamhane's T2 \\
\hline \multirow{4}{*}{$\begin{array}{l}\text { Egzersiz yaparsam kendi } \\
\text { kendime sakatlanırım diye } \\
\text { korkuyorum }\end{array}$} & (1) $18-35$ & 53 & 45,60 & \multirow{4}{*}{7,032} & \multirow{4}{*}{3} & \multirow{4}{*}{071} & \\
\hline & (2) $26-35$ & 8 & 56,00 & & & & \\
\hline & (3) $36-45$ & 19 & 50,39 & & & & \\
\hline & (4) $46-59$ & 34 & 67,57 & & & & \\
\hline \multirow{4}{*}{$\begin{array}{l}\text { Ağrımla baş etmeye çalışacak } \\
\text { olsam ağrım artar }\end{array}$} & (1) $18-35$ & 53 & 49,22 & \multirow{4}{*}{11,117} & \multirow{4}{*}{3} & \multirow{4}{*}{,011 } & \\
\hline & (2) $26-35$ & 8 & 52,38 & & & & \\
\hline & (3) $36-45$ & 19 & 55,13 & & & & $3>1$ \\
\hline & (4) $46-59$ & 34 & 66,29 & & & & \\
\hline \multirow{4}{*}{$\begin{array}{l}\text { Ağrımdan dolayı vücudum bana } \\
\text { tehlikeli derecede yanlış giden } \\
\text { bir şeyler olduğunu söylüyor }\end{array}$} & (1) $18-35$ & 53 & 56,51 & \multirow{4}{*}{1,666} & \multirow{4}{*}{3} & \multirow{4}{*}{,645 } & \\
\hline & (2) $26-35$ & 8 & 47,31 & & & & \\
\hline & (3) $36-45$ & 19 & 63,45 & & & & \\
\hline & (4) $46-59$ & 34 & 58,12 & & & & \\
\hline \multirow{4}{*}{$\begin{array}{l}\text { Egzersiz yaparsam sanki ağrım } \\
\text { hafifleyecekmiş gibi geliyor }\end{array}$} & (1) $18-35$ & 53 & 49,86 & \multirow{4}{*}{8,090} & \multirow{4}{*}{3} & \multirow{4}{*}{,044 } & \\
\hline & (2) $26-35$ & 8 & 56,69 & & & & \\
\hline & (3) $36-45$ & 19 & 67,84 & & & & \\
\hline & (4) $46-59$ & 34 & 67,74 & & & & $4>1$ \\
\hline \multirow{4}{*}{$\begin{array}{l}\text { İnsanlar benim tıbbi sorunlarımı } \\
\text { yeterince ciddiye almıyorlar }\end{array}$} & (1) $18-35$ & 53 & 53,55 & \multirow{4}{*}{4,353} & \multirow{4}{*}{3} & \multirow{4}{*}{,226 } & \\
\hline & (2) $26-35$ & 8 & 72,75 & & & & \\
\hline & (3) $36-45$ & 19 & 52,84 & & & & \\
\hline & (4) $46-59$ & 34 & 62,68 & & & & \\
\hline \multirow{4}{*}{$\begin{array}{l}\text { Başıma gelen bu olay nedeni ile } \\
\text { vücudum hayat boyu risk } \\
\text { altında olacak }\end{array}$} & (1) $18-35$ & 53 & 49,26 & \multirow{4}{*}{9,075} & \multirow{4}{*}{3} & \multirow{4}{*}{,028 } & \\
\hline & (2) $26-35$ & 8 & 59,75 & & & & \\
\hline & (3) $36-45$ & 19 & 63,89 & & & & \\
\hline & (4) $46-59$ & 34 & 66,24 & & & & $4>1$ \\
\hline \multirow{4}{*}{$\begin{array}{l}\text { Ağrımın olması her zaman } \\
\text { vücudumu sakatladığım/bir } \\
\text { problemim olduğu anlamına } \\
\text { gelir }\end{array}$} & (1) $18-35$ & 53 & 51,63 & \multirow{4}{*}{4,458} & \multirow{4}{*}{3} & & \\
\hline & (2) $26-35$ & 8 & 64,56 & & & 216 & \\
\hline & (3) $36-45$ & 19 & 59,82 & & & , & \\
\hline & (4) $46-59$ & 34 & 63,69 & & & & \\
\hline & (1) $18-35$ & 53 & 58,81 & & & & \\
\hline $\begin{array}{l}\text { Sirt bazı şeylerin agrimı } \\
\text { arturivor olması onların tehlikeli }\end{array}$ & (2) $26-35$ & 8 & 65,25 & 2104 & 3 & 533 & \\
\hline oldukları anlamina gelmez & (3) $36-45$ & 19 & 50,21 & 2,194 & 3 & מ & \\
\hline & (4) $46-59$ & 34 & 57,71 & & & & \\
\hline & (1) $18-35$ & 53 & 59,91 & & & & \\
\hline Kendimi kazara sakatlamaktan & (2) $26-35$ & 8 & 70,69 & 2086 & 3 & 304 & \\
\hline korkuyorum & (3) $36-45$ & 19 & 53,39 & 2,900 & 3 & , 594 & \\
\hline & (4) $46-59$ & 34 & 52,94 & & & & \\
\hline
\end{tabular}


Tablo 4 (Devamı). Sedanter bireylerin yaş değişkenine göre kinezyofobilerinin karşılaştırılması

\begin{tabular}{|c|c|c|c|c|c|c|c|}
\hline & Yaş & $\mathbf{N}$ & Sura Ort. & $\mathbf{X}^{2}$ & sd & $p$ & Tamhane's T2 \\
\hline \multirow{4}{*}{$\begin{array}{l}\text { Ağrının artmasını engellemenin } \\
\text { en basit ve güvenli yolu } \\
\text { gereksiz hareketler yapmaktan } \\
\text { kaçınmaktır }\end{array}$} & (1) $18-35$ & 53 & 61,27 & \multirow{4}{*}{3,229} & \multirow{4}{*}{3} & \multirow{4}{*}{,358 } & \\
\hline & (2) $26-35$ & 8 & 64,31 & & & & \\
\hline & (3) $36-45$ & 19 & 47,76 & & & & \\
\hline & (4) $46-59$ & 34 & 55,46 & & & & \\
\hline \multirow{4}{*}{$\begin{array}{l}\text { Vücudumda tehlike arz eden bir } \\
\text { şey olmasaydı bu kadar çok ağrı } \\
\text { hissetmezdim }\end{array}$} & (1) $18-35$ & 53 & 53,81 & \multirow{4}{*}{3,223} & \multirow{4}{*}{3} & \multirow{4}{*}{,358 } & \\
\hline & (2) $26-35$ & 8 & 47,69 & & & & \\
\hline & (3) $36-45$ & 19 & 63,82 & & & & \\
\hline & (4) $46-59$ & 34 & 62,03 & & & & \\
\hline \multirow{4}{*}{$\begin{array}{l}\text { Ağrıma rağmen fiziksel olarak } \\
\text { aktif olsaydım durumum daha } \\
\text { iyi olurdu }\end{array}$} & (1) $18-35$ & 53 & 58,91 & \multirow{4}{*}{3,307} & \multirow{4}{*}{3} & \multirow{4}{*}{,347 } & \\
\hline & (2) $26-35$ & 8 & 72,25 & & & & \\
\hline & (3) $36-45$ & 19 & 52,16 & & & & \\
\hline & (4) $46-59$ & 34 & 54,82 & & & & \\
\hline \multirow{4}{*}{$\begin{array}{l}\text { Ağnı kendimi sakatlamamam } \\
\text { için egzersizi ne zaman } \\
\text { bırakmam gerektiği konusunda } \\
\text { bana sinyal verir }\end{array}$} & (1) $18-35$ & 53 & 51,75 & \multirow{4}{*}{5,275} & \multirow{4}{*}{3} & \multirow{4}{*}{,153 } & \\
\hline & (2) $26-35$ & 8 & 66,38 & & & & \\
\hline & (3) $36-45$ & 19 & 67,76 & & & & \\
\hline & (4) $46-59$ & 34 & 58,65 & & & & \\
\hline \multirow{4}{*}{$\begin{array}{l}\text { Benim durumumda olan birinin } \\
\text { fiziksel olarak aktif olması pek } \\
\text { güvenli değildir }\end{array}$} & (1) $18-35$ & 53 & 54,65 & \multirow{4}{*}{6,813} & \multirow{4}{*}{3} & \multirow{4}{*}{,078 } & \\
\hline & (2) $26-35$ & 8 & 55,06 & & & & \\
\hline & (3) $36-45$ & 19 & 48,53 & & & & \\
\hline & (4) $46-59$ & 34 & 67,53 & & & & \\
\hline \multirow{4}{*}{$\begin{array}{l}\text { Normal insanların yaptığı her } \\
\text { şeyi yapamam çünkü çok kolay } \\
\text { sakatlanırım }\end{array}$} & (1) $18-35$ & 53 & 54,20 & \multirow{4}{*}{4,250} & \multirow{4}{*}{3} & \multirow{4}{*}{,236 } & \\
\hline & (2) $26-35$ & 8 & 57,75 & & & & \\
\hline & (3) $36-45$ & 19 & 51,66 & & & & \\
\hline & (4) $46-59$ & 34 & 65,85 & & & & \\
\hline \multirow{4}{*}{$\begin{array}{l}\text { Bazı şeyler çok fazla ağrıya } \\
\text { neden olsa bile bunların } \\
\text { gerçekte tehlikeli olduklarını } \\
\text { düşünmem }\end{array}$} & (1) $18-35$ & 53 & 58,11 & \multirow{4}{*}{5,579} & \multirow{4}{*}{3} & \multirow{4}{*}{\multicolumn{2}{|c|}{,134 }} \\
\hline & (2) $26-35$ & 8 & 56,06 & & & & \\
\hline & (3) $36-45$ & 19 & 44,42 & & & & \\
\hline & (4) $46-59$ & 34 & 64,19 & & & & \\
\hline \multirow{4}{*}{$\begin{array}{l}\text { Hiç kimse ağrı hissederken } \\
\text { egzersiz yapmak zorunda } \\
\text { olmamalı }\end{array}$} & (1) $18-35$ & 53 & 60,00 & & & & \\
\hline & (2) $26-35$ & 8 & 54,75 & & & & \\
\hline & (3) $36-45$ & 19 & 61,74 & 1,196 & 3 & ,590 & \\
\hline & (4) $46-59$ & 34 & 51,88 & & & & \\
\hline
\end{tabular}

Yaş değişkeni açısından, sedanter bireylerin, A ̈̆rımla baş etmeye çalışacak olsam ăgrım artar, Egzersiz yaparsam sanki ă̆rım hafifleyecekmiş gibi geliyor, Başıma gelen bu olay nedeni ile vücudum hayat boyu risk altında olacak, maddelerinde istatistiksel olarak anlaml bir fark görülmüştür (Tablo 4) $(\mathrm{p}<0,05)$. Farkın hangi gruplar arasında oluştuğunu tespit 
etmek için yapılan Post-Hoc (Tamhane's T2) test sonucuna göre, yaş aralığı 18-35 olanlar ile 46-59 arasında olan bireyler arasında olduğu görülmektedir.

\section{TARTIŞMA VE SONUÇ}

Cinsiyet açısından elde edilen sonuçlara kaıldığında, Egzersiz yaparsam kendi kendime sakatlanırım diye korkuyorum, Ă̆rımla baş etmeye çalışacak olsam ă̆rım artar, Kendimi kazara sakatlamaktan korkuyorum maddelerinde erkekler lehine, Ăgr kendimi sakatlamamam için egzersizi ne zaman bırakmam gerektiği konusunda bana sinyal verir maddelerinde kadınlar ve erkekler arasında anlamlı bir fark tespit edilmiştir $(p<0,05)$ (Tablo 2). Kinezyofobi değerlerinin kadınlar lehine daha düşük olduğu görülmüştür. Kadınların genel olarak daha hassas bir yapıda olmaları buna neden olmuş olabilir. Lüning Bergsten ve diğerleri (2012) tarafından yapılan çalışmada, erkeklerin kinezyofobi puanlarının kadınlara göre daha yüksek çıktığını rapor edilirken, Özmen ve diğerleri (2016) tarafından yapılan çalışmada ise kadınların kinezyofobisinin daha yüksek çıktığı rapor edilmiştir.

Eğitim durumu açısından elde edilen sonuçlara bakıldında, Egzersiz yaparsam kendi kendime sakatlanırım diye korkuyorum, Başıma gelen bu olay nedeni ile vücudum hayat boyu risk altında olacak, Vücudumda tehlike arz eden bir şey olmasaydl bu kadar çok ă̆r hissetmezdim maddeleri arasında anlamlı bi fark görülmüştür $(\mathrm{p}<0,05)$ (Tablo 3). Bu farkın yapılan Post Hoc (Tamhane's T2) analizi ile de üniversite ile ortaokul arasında ve üniversite lehine daha düşük kinezyofobi olduğu saptanmıştır. Bunun sebebi bireylerin almış oldukları akademik eğitimle bu konuda daha bilinçlenmeleri olabilir. Diğer bir yandan üniversite eğitimi ile sahip olunan vasıflı mesleğin getirileri ile kişinin hayat standardının artmış olması da önemli rol oynamış olabilir. Ertan ve diğerlerinin (2019) yaptığı çalışmada eğitim düzeyi düşük olan kişilerin kinezyofobi değerlerinin daha yüksek olduğu görülmüştür. Ayrıca Uçurum ve Kalkan (2018) tarafından yapılan çalışmada da eğitim durumu ile kinezyofobi arasında negatif bir korelasyon saptanmıştır. Bunlara ek olarak Güzel ve diğerlerinin (2021) yaptığı çalışmada da nüfusa oranla eğitim seviyesi daha yüksek olan kişilerin kinezyofobi durumunun daha az olduğu saptanmıştır.

Yaş açısından elde edilen sonuçlara bakıldında, Ă̆rımla baş etmeye çalışacak olsam ă̆rım artar, Egzersiz yaparsam sanki ăgrım hafifleyecekmiş gibi geliyor, Başıma gelen bu olay nedeni ile vücudum hayat boyu risk altında olacak, maddelerinde anlamlı bir fark görülmüştür $(\mathrm{p}<0,05)$ (Tablo 4). Görülen bu farkın yapılan Post Hoc (Tamhane's T2) testi ile analiz edildiğinde 18-35 yaş grubu ile 46-59 yaş grubu arasında ve 18-35 yaş grubu lehine daha düşük bir kinezyofobi görüldüğü saptanmıştır. Bunun nedeni ilerleyen yaşlar beraber azalan hareket ile vücudun tembelleşip güçsüzleşmesi ve yaş ilerledikçe vücutta oluşan deformitelere bağlı olduğu düşünülebilir. Yaşın ilerlemesi ile yaşam kalitesinin düşmesi de nedenlerden biri olabilir. Tugay ve Karadeniz'in (2020) yaptığı çalışmada ileri yaştaki bireylerin daha fazla kinezyofobiye sahip olduğu tespit edilmiştir. Pirinççi ve diğerlerinin (2021) yaptığı çalışmada yaş ve kinezyofobi değerleri arasında bir bağlantı bulunamamıştır.

Sonuç olarak, araştırmada elde edilen bulgulara göre cinsiyet, eğitim durumu ve yaş değişkenleri açısından ölçeğin belirtilen maddelerinde bireyler arasında farklar görülmüştür. 
Yukarıda elde ettiğimiz sonuçlara göre kinezyofobi sedanterlerde çeşitli değişkenler doğrultusunda etkilenip değişkenlik gösterebilmektedir.

Sedanter bireylerin bu konuda bilinçlendirilmesi açısından sempozyum, konferans gibi etkinlikler düzenlenmesinin olumlu sonuçlarının olacağı düşünülmektedir. Bu bilgilendirme işleminde alanında uzman eğitimciler ve akademisyenler tarafından verilmesi oluşabilecek bilgi kirliliğinin önüne geçilmesinde de etkili olacağı düşünülmektedir.

Yayın Etiği: $\mathrm{Bu}$ çalışmanın hazırlanma ve yazım sürecinde "Yükseköğretim Kurumları Bilimsel Araştırma ve Yayın Etiği Yönergesi" kapsamında bilimsel, etik ve alıntı kurallarına uyulmuş olup; toplanan veriler üzerinde herhangi bir tahrifat yapılmamış ve bu çalışma herhangi başka bir akademik yayın ortamına değerlendirme için gönderilmemiş̧ir. Alıntılama yapılan araştırmalara atıf yapılarak etik kurallara riayet edilmiştir.

Çıkar Çatışması: Yazarlar arasında herhangi bir çıkar çatışması yoktur.

Araştırmacıların Katkı Oranı Beyanı: Birinci yazar olan Furkan ERGÜL araştırmanın, Giriş ve yöntem kısmında etkin bir rol oynamıştır. Yazarlardan Hulusi ALP araştırmanın istatistik analizlerini ve Bulgular kısmında etkin rol oynamıştır. Her iki yazar araştırmanın tartışma ve sonuç kısmını birlikte tamamlamışlardır. 


\section{KAYNAKLAR}

Bilge, C. (2017). Adheziv kapsülitli hastalarda ă̆rinin fonksiyonellik, kinezyofobi, uyku kalitesi ve yaşam kalitesine etkisi. Bezmialem Vakif Üniversitesi, Sağlik Bilimleri Enstitüsü, Fizyoterapi ve Rehabilitasyon Anabilim Dalı, Yayımlanmış Yüksek Lisans Tezi.

Çobanoğlı, İ.H. (2020). Araştırmada örneklemin belirlenmesi. E. Oğuz (Eds). Eğitimde araştırma yöntemleri. Ankara: Eğiten Kitap, s.119-140.

Dere, T. (2020). Servikal disk hernili bireylerde kassal enduransin ă̆ri, boyun farkındalı̆̆ ve kinezyofobi ile ilişkisinin incelenmesi. Hacettepe Üniversitesi, Sağlık Bilimleri Enstitüsü, Nöroloji Fizyoterapistliği Programı, Yayımlanmış Yüksek Lisans Tezi.

Devaşan, G. (2014). Romatizmal hastalıklarda klinik pilates terapinin kinezyofobi üzerindeki etkinliğinin araştırılması. Hacettepe Üniversitesi, Sağlık Bilimleri Enstitüsü, Fizik Tedavi ve Rehabilitasyon Anabilim Dalı, Yayımlanmış Yüksek Lisans Tezi.

Duran, M.A. (2020). Tenis oyuncularının ve sedanterlerin alt-üst ekstremite kas değerlerinin çabukluk ve dayanıklılık performansına etkisi. İstanbul Gelişim Üniversitesi, Sağlık Bilimleri Enstitisü, Antrenörlük Eğitimi Anabilim Dalı, Yayımlanmış Yüksek Lisans Tezi.

Ertan, Ö., Kuran A.G., Akıncı, B. ve Okumuş N. G. (2019). Pulmoner hipertansiyonlu bireylerde kinezyofobi. Türk Fizyoterapi ve Rehabilitasyon Dergisi, 30(3), 168-175.

Güney, G. (2019). Total diz artroplastili bireylerde aktivite öz algısının kinezyofobi ve fonksiyonel iyileşmeye etkisi. Hacettepe Üniversitesi, Sağlik Bilimleri Enstitüsü, Ergoterapi Programı, Yayımlanmış Yüksek Lisans Tezi.

Güzel, R., İrdesel, J. ve Kutsal, F.Y.G. (2021). İleri yaşlarda kinezyofobi. Sürekli Tıp Eğitim Dergisi, 30(2), 116-125.

Haspolar, M. 2017. Meme kanseri cerrahisi geçiren kadınlarda kinezyofobi, üst ekstremite fonksiyonu, lenfödem, ă̆rı, duyu ve depresyon ilişkisi. Gazi Üniversitesi Sağlık Bilimleri Enstitüsü, Fizyoterapi ve Rehabilitasyon Anabilim Dalı, Yayımlanmış Yüksek Lisans Tezi.

İlhan, A., Çelik, H.C. ve Aslan, A. (2016). Üniversite öğrencilerinin bilimsel araştırmaya yönelik tutumlarının incelenmesi. İnönü Üniversitesi Ë̆itim Fakültesi Dergisi, 17(2), 141-156.

Kaygusuz, R. (2018). Koroner arter hastalı̆̆ında komorbidite ve fonksiyonel kapasitenin kinezyofobi ile ilişkisinin değerlendirilmesi. Marmara Üniversitesi, Sağlı Bilimleri Enstitüsü, Fizyoterapi ve Rehabilitasyon Anabilim Dalı, Yayımlanmış Yüksek Lisans Tezi.

Kori, S.H., Miller, R.P. \& Todd D. (1990). Kinesophobia: A new view of chronic pain behaviour. Pain Management, 1(3), 35-43.

Lungberg, M., Larsson, M. E. H., Ostlund, H. \& Jorma, S. (2006). Kinesiophobia among patients with musculoskeletal pain inprimary healthcare. Journal of Rehabilitation Medicine, 38(1), 37-43. Doi:10.1080/16501970510041253

Lüning, B.C., Lundberg, M., Lindberg, P. \& Elfving, B. (2012). Change in kinesiophobia and its relation to activity limitation after multidisciplinary rehabilitation in patients with chronic back pain. Disabil Rehabilitation, 34(10), 852-858.

Özkal, Ö., Topuz S., Konan A. ve Kısmet K. (2017). Alt ekstremite yanık yaralanması olan bireylerde ağr1, kinezyofobi, denge ve fonksiyonellik arasındaki ilişkinin incelenmesi. Ankara Eğitim ve Araştırma Hastanesi Dergisi, 50(3), 122-128.

Özmen, T., Gündüz, R., Doğan, H., Zoroğlu, T. \& Acar, D. (2016). Relationship between kinesiophobia and quality of life in patients with low. Fırat Üniversitesi Săglık Bilimleri Tıp Dergisi, 30(1), 1-4. 
Pirinççi, C.Ş., Cihan, E., Arca, M., Durmaz, E.D. ve Yıldırım, N.Ü. (2021). Ağrılı omuz patolojilerinde görülen kinezyofobinin yaşam kalitesi ve omuz fonksiyonelliğine olan etkisi. Anadolu Kliniği Tip Bilimleri Dergisi, 26(1), 3-10. DOI: 10.21673/anadoluklin.755320

Sarıdede, Ö.C. (2019). Pilates egzersizinin sedanter insanlar üzerindeki etkileri. İstanbul Gelişim Üniversitesi, Sağlık Bilimleri Enstitüsü, Antrenörlük Anabilim Dalı, Yayınlamış Yüksek Lisans Tezi.

Şata, M. (2020). Nicel araştırma yöntemleri. E. Oğuz (Eds). Eğitimde araştırma yöntemleri (77-97). Ankara: Eğiten Kitap.

Tekin, A. (2010). Lumbal disk hernisi ve spinal stenoz olgularında ilgili anatomik bölgenin radyolojik ve klinik bulgular ile değerlendirilmesi. Kocaeli Üniversitesi, Sağlık Bilimleri Enstitüsü, Anatomi Anabilim Dalı, Yayımlanmış Yüksek Lisans Tezi.

Tugay, T. ve Karedeniz, P.G. (2020). Postmenopozal osteoporozlu kadınlarda kinezyofobinin yaşam kalitesi üzerine etkisi. KSU Tip Fakültesi Dergisi, 15(3), 0-46.

Uçurum, S.G. ve Kalkan, A.C. (2018). Bel ağrılı hastalarda ağrı, kinezyofobi ve yaşam kalitesi arasındaki ilişki. Ege Tip Dergisi, 57(3), 131-135.

Uzun, T. ve Ayık, A. (2016). Okul müdürlerinin iletişim becerileri ile öğretmenlerin genel ve örgütsel sinizm tutumları arasındaki ilişkilerin incelenmesi. Mersin Üniversitesi Eğitim Fakültesi Dergisi,12(2), 672-688.

Vlaeyen, J.W., Kole-Snijders, A.M. \& Boeren, R.G. (1995). Fear of movement/(re)injury in chronic low back pain and its relation to behavioral performance. Pain, 62(3), 363-372. doi: 10.1016/0304-3959(94)00279N.

Yılmaz, Ö.T., Yakut, Y., Uygur, F. \& Uluğ, N. (2011). Tampa kinezyofobi ölçeğinin Türkçe versiyonu ve testtekrar test güvenirliği. Fizyoterapi ve Rehabilitasyon Dergisi, 22(1), 44-49.

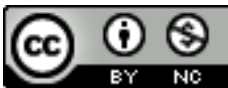

Bu eser Creative Commons Atıf-Gayri Ticari 4.0 Uluslararası Lisansı ile lisanslanmıștır. 